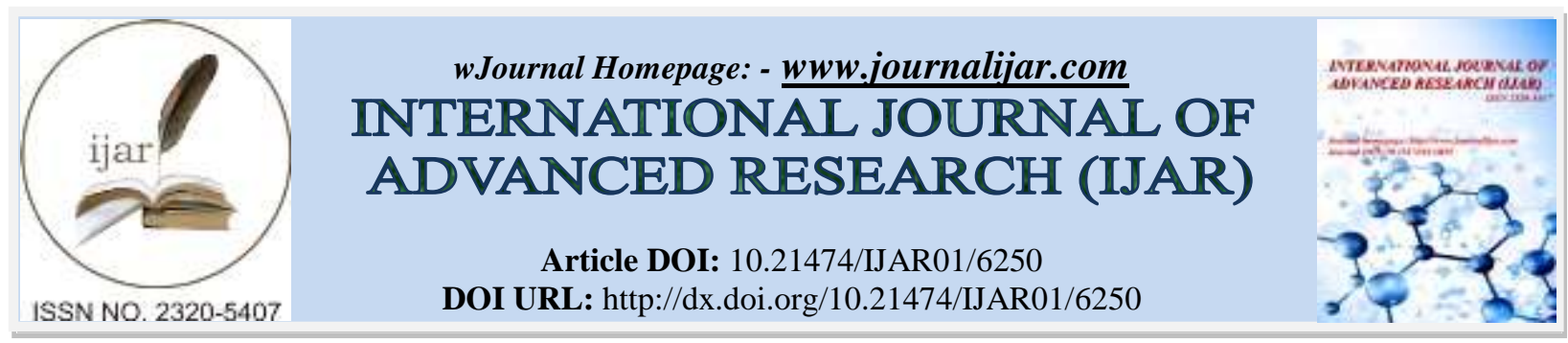

RESEARCH ARTICLE

\title{
NUTRITIONAL AND PHYTOCHEMICAL STUDIES OF Jatropha tanjorensis Ellis \& Saroja UNDER VARIED SOIL CONDITIONS.
}

Mbosowo M. Etukudo ${ }^{1}$ and Samuel E. Osim ${ }^{2}$.

1. Department of Biology, Federal University Otuoke, PMB 126, Bayelsa State, Nigeria.

2. Department of Biological Sciences, Cross River University of Technology, Calabar, Cross River State, Nigeria.

\section{Manuscript Info}

Manuscript History

Received: 08 November 2017

Final Accepted: 10 December 2017

Published: January 2018

Keywords:-

Nutritional, phytochemical, Jatropha

tanjorensis, soil.

\section{Abstract}

Introduction: This present study was carried out to assess the mineral nutrient and phytochemical properties in leaves of the test plant and the influence of soil properties on them.

Methods: Leaves of $J$. tanyorensis obtained from two sampling locations (Akwa Ibom State-L1 and Bayelsa State-L2), were analysed for phytochemical and mineral nutrient contents using standard procedures. The physico-chemical properties of soils in the sampling locations were also assessed.

Results: There were variations in soil physico-chemical properties between the two sampling locations. There were marked variations $(\mathrm{P}<0.05)$ in elemental nutrient and phytochemical compositions in leaves of $J$. tanyorensis between the two sampling locations.

Conclusion: This study suggests that the soil conditions in L1 sampling location enhanced the phytochemical and mineral nutrient contents in leaves of $J$. tanyorensis than that of L2 location. Therefore, appropriate soil improvement practices are required in L2 sampling location in order to improve the biochemical properties of this important species.

Copy Right, IJAR, 2018,. All rights reserved.

\section{Introduction:-}

In some areas, rapid industrialization has generated changes in soil physico-chemical properties due to pollution and climatic changes [1, 2]. Environmental disturbances resulting from mining and road construction activities also contribute to changes in soil quality [ 3 ], and in consequence affect the elemental composition in plants [4 ]. Climatic change has been reported to have a great influence on the life cycle, distribution and phytochemical composition of the world's vegetation [5 ]. Phytochemical composition of medicinal plants is known to be affected by a number of environmental factors such as altitude, soil type and change of season [ 6, 7, 8 ].

The medicinal value of plants like antimicrobial, anti-inflamatory, antidiabetic, antioxidant, antidiuretic among others mainly depend on the secondary metabolites, and the most important bioactive compounds are alkaloids, saponins, flavonoids, tannins, sterols and phenolic compounds [9, 10]. Jatropha tanjorensis (family Euphorbiaceae) is an important species usually utilized for medicinal and nutritional purposes, and exhibit intermediacy in phenotypic characters between J. gossypifolia and J. curcas [11]. It has common names such as hospital too far, Catholic vegetable, Iyana-ipaja, lapalapa [12]. It is utilized majorly for fencing while its other uses are as a source of edible leafy vegetable and as medicine [13]. Research on toxicity and histopathological studies of the leaf 
extract on rats showed no significant abnormalities in the tissues, but has a mild effects on the lungs and liver [14]. The herbal medicine from this species is prepared by squeezing the leaves to obtain a juice [11]. It is a good dietary source of mineral elements, since it compares favorably with other food substances in contents of trace elements such as zinc, iron and selenium $[15,16]$. The antimicrobial properties of the leaf extract has been shown to inhibit the growth of $S$. aureus and E.coli [16].

It is important to note that natural food and food ingredients from plants have been proven to be safer and healthier than their synthetic ones [17], therefore studies on this species becomes a worthwhile pursuit. Understanding how declining soil fertility influence the growth, and production of mineral nutrients and secondary metabolites have attracted considerable attention to evaluate the influence of soil status on the mineral nutrients and phytochemical contents of the test plants.

\section{Materials and methods:-}

Study Area: The research was carried out in Abak in Akwa Ibom State (L1) and Yenagoa in Bayelsa State (L2), both in Nigeria. Abak has coordinates of $4^{0} 33{ }^{\wedge} \mathrm{N}$ and $7^{0} 33^{`} \mathrm{E}$. Akwa Ibom State is located within the humid tropical rainforest Zone of South eastern Nigeria with a mean annual rainfall of about 2000mm, while the mean annual minimum and maximum temperature are $23^{\circ} \mathrm{C}$ and $31.7^{\circ} \mathrm{C}$, respectively $[18,19]$. Yenagoa is located at coordinates of $4^{\circ} 55^{\prime} 33.51^{\prime \prime} \mathrm{N}$ and $6^{\circ} 15^{\prime} 33.58^{\prime \prime E}$. Bayelsa State lies in the heaviest rainfall area of Nigeria with a mean minimum monthly temperature ranging from $25^{\circ} \mathrm{C}$ to $31^{\circ} \mathrm{C}[20]$.

Collection of Samples: Plant materials (leaves) of the test species were collected from the two (2) sampling location, Abak in Akwa Ibom State (L1) and Yenagoa in Bayelsa State (L2), both in Nigeria. Similarly, soil samples of L1 and L2 were collected for determination of soil- chemical properties. Three replicates were maintained per treatment using completely randomized design.

Analysis of Soil samples: Top soils of about $0-20 \mathrm{~cm}$ depth collected from the study areas were analysed for soilchemical properties $(\mathrm{pH}$, organic carbon, total nitrogen, available Phosphorus, calcium, magnesium, potassium, zinc, copper, cadmium, iron and lead) using standard procedures [21].

\section{Phytochemical analysis in Plant samples:-}

The leaves of the test plant were analysed for the amounts of simple alkaloids, tannins, flavonoids, saponins, and glycosides using standard procedures [22, 23, 24, 25$]$.

\section{Mineral nutrient Analysis in Plant Samples:-}

The method of [26 ] was used for mineral elements analysis in plant samples. Leaf samples of Jatropha taryorensis were washed several times with water and rinsed with distilled water. They were placed in polybags, and thereafter dried in an oven maintained at $60^{\circ} \mathrm{C}$ to a constant weight. The dried plant samples were macerated to powder, and stored in sample bottles for analysis. The powdered plant samples were oven dried at $105^{\circ} \mathrm{C}$ for 2 hours, $1.0 \mathrm{~g}$ weighed into a platinum crucible and placed in a muffle furnace maintained at $400^{\circ} \mathrm{C}$. The powdered plant materials were ashed for 5 hours and then dissolved with $10 \mathrm{~cm}^{3}$ of $1 \mathrm{M}$ HCL. The solution obtained was filtered through Whatman No. 1 filter paper into $50 \mathrm{~cm}^{3}$ volumetric flask and made up to the required mark with distilled deionized water. Standard reagents for analytical experiment were used, and contents of mineral elements in the solution were determined using Atomic Absorption Spectrophotometer (AAS) of Unicam Model.

\section{Statistical Analysis:-}

The data generated from this study were assessed using Analysis of variance (ANOVA) and differences in the means were tested using Least Significant Differences (LSD) at probability level of 5\% [27]..

\section{Results:-}

The $\mathrm{pH}$ value of soils in L1 and L2 sampling locations were 5.10 and 5.30, respectively. The contents of total nitrogen, available phosphorus, calcium, magnesium, zinc, cadmium, lead and manganese in soil of L1 were comparatively $(\mathrm{P}<0.05)$ higher than those of L2 sampling location, while the organic carbon, potassium, copper and iron contents in soil of L2 sampling location were significantly $(\mathrm{P}<0.05)$ higher than those of L1 (Table 1). The alkaloids, tannins, saponins and glycosides contents in leaves of Jatropha tanyorensis in L1 sampling location were relatively higher $(\mathrm{P}<0.05)$ than those of $\mathrm{L} 2$, while the flavonoids contents were higher than those of L1 sampling 
location (Table 2). Higher contents of calcium, nitrogen, phosphorus, sodium, manganese, zinc and lead were recorded in leaves of $J$. tanyorensis in L1 relative to those of L2 sampling location. The leaves of $J$. tanyorensis recorded higher contents of magnesium, potassium, iron and copper which were relatively higher $(\mathrm{P}<0.05)$ than those of L1 sampling location (Table 3).

Table 1:- Chemical Properties of Experimental Soils

\begin{tabular}{|l|lc|}
\hline Soil parameters & \multicolumn{2}{c|}{ Sampling locations } \\
\hline \multirow{2}{*}{ pH } & L1 (Abak) & L2 (Yenagoa) \\
\cline { 2 - 3 } Organic carbon $(\%)$ & $5.30 \pm 0.92$ & $5.10 \pm 0.24$ \\
Total nitrogen $(\%)$ & $1.44 \pm 0.34$ & $2.06 \pm 0.53$ \\
Avail. Phosphorus $(\%)$ & $2.63 \pm 0.55$ & $1.69 \pm 0.70$ \\
Calcium (mg/100g) & $5.07 \pm 0.40$ & $3.21 \pm 0.41$ \\
Magnesium (mg/100g) & $3.37 \pm 0.23$ & $2.67 \pm 0.24$ \\
Potassium (mg/100g) & $3.19 \pm 0.21$ & $2.17 \pm 0.19$ \\
Zinc (mg/100g) & $1.72 \pm 0.32$ & $2.82 \pm 0.58$ \\
Copper $(\mathrm{mg} / 100 \mathrm{~g})$ & $0.17 \pm 0.01$ & $0.14 \pm 0.06$ \\
Cadmium (mg/100g) & $0.35 \pm 0.07$ & $0.40 \pm 0.09$ \\
Iron $(\mathrm{mg} / 100 \mathrm{~g})$ & $0.21 \pm 0.02$ & $0.10 \pm 0.02$ \\
Lead $(\mathrm{mg} / 100 \mathrm{~g})$ & $0.17 \pm 0.04$ & $0.21 \pm 0.04$ \\
Manganese $(\mathrm{mg} / 100 \mathrm{~g})$ & $0.08 \pm 0.01$ & $0.03 \pm 0.01$ \\
\hline
\end{tabular}

Mean \pm standard error from three replicates

Table 2:- Quantitative analysis of phytochemical constituents in leaves of Jatropha tanjorensis

\begin{tabular}{|l|lc|}
\hline Phytochemicals & \multicolumn{2}{|c|}{ Sampling locations } \\
\hline & L1 (Abak) & \multicolumn{1}{c|}{ L2 (Yenagoa) } \\
\cline { 2 - 3 } Alkaloids (\%) & $22.20 \pm 0.31$ & $20.40 \pm 0.33$ \\
Tannins (\%) & $34.60 \pm 0.46$ & $30.20 \pm 0.80$ \\
Flavonoids (\%) & $11.20 \pm 0.50$ & $13.50 \pm 0.27$ \\
Saponins (\%) & $20.40 \pm 0.22$ & $18.10 \pm 0.45$ \\
Glycosides (\%) & $10.09 \pm 0.26$ & $8.22 \pm 0.76$ \\
\hline
\end{tabular}

Mean \pm standard error from three replicates

Table 3:- Mineral elements in Leaves of Jatropha tanjorensis

\begin{tabular}{|l|cc|}
\hline Mineral elements (mg/100g) & \multicolumn{2}{|c|}{ Sampling locations } \\
\hline & L1 (Abak) & L2 (Yenagoa) \\
\cline { 2 - 3 } Calcium & $16.50 \pm 0.21$ & $14.20 \pm 0.30$ \\
Sodium & $10.86 \pm 0.33$ & $11.92 \pm 0.45$ \\
Potassium & $21.80 \pm 0.72$ & $17.21 \pm 0.67$ \\
Nitrogen & $14.90 \pm 0.35$ & $16.07 \pm 0.56$ \\
Phosphorus & $4.20 \pm 0.54$ & $3.80 \pm 0.31$ \\
Iron & $0.50 \pm 0.07$ & $0.37 \pm 0.03$ \\
Manganese & $0.14 \pm 0.03$ & $0.18 \pm 0.04$ \\
Copper & $0.034 \pm 0.01$ & $0.028 \pm 0.02$ \\
Zinc & $0.012 \pm 0.00$ & $0.016 \pm 0.01$ \\
Lead & $0.58 \pm 0.03$ & $0.50 \pm 0.03$ \\
\hline
\end{tabular}

Mean \pm standard error from three replicates

\section{Discussion:-}

There were variations in phytochemical contents in leaves of $J$. tanyorensis between the two sampling locations. These differences may be due to variation in the prevailing environmental factors in the two habitats. This result agrees with the work of [28] that bioactive compounds are secondary metabolites, which are affected by both environmental and plant nutrition factors. The production and activity of bioactive compounds are influenced by genetics and the environmental factors surrounding the habitat [ 7, 8 ]. Different agro-climatic conditions have been reported to have effects on the alkaloids, phenols, flavonoids, saponins, terpenes, total phenolic contents and antioxidant potential of Aloe Vera plant [5 ]. Improvement in soil fertility through application of organic amendment has been shown to increase the water content and the maturity stage of the leaves, thus contributing to a reduction in the content of total and individual glucosinolates as well as flavonoids and anthocyanins [29]. Soil properties such as 
water status can inhibit primary metabolism and energy balance of the plant as well as alter the secondary metabolism of plant, and its sequestration of different plants [ 30, 31 ].

There were significant variations in elemental composition in leaves of $J$. tanyorensis between L1 and L2 sampling locations. This low nutrient composition in L2 location relative to L1 may be attributed to poor topography terrains that characterized the soil of L2 sampling location, together with environmental problems such as flooding and intense riverine setting of the habitat [4]. Eco-physiological influenced changes in plants elemental composition have been reported $[32,33]$. Several factors such as age, cultural practices, environment, the season and the varieties have been reported to influence the nutrient composition of plants [ 34 ]. Factors such as pH, available nutrients, texture, organic matter content, soil water relationship, weather and climate factors among others have been reported to directly or indirectly affect the nutritional quality of plants [5]. In addition, soil $\mathrm{pH}$ and organic matter affect plant nutrient availability and soil functions. To a great extent, $\mathrm{pH}$ influence solubility, and availability of plant nutrients, and organic matter decomposition [35]. Soil organic matter, which is the key indicator to soil quality affects nutrient retention, water holding capacity and soil aggregation, in consequence influence the nutrient status of plant material [35].

\section{Conclusion:-}

This study shows that soil conditions have a strong influence on biochemical constituents of plants. The soil conditions in L1 sampling location enhanced the phytochemical and mineral nutrient contents in leaves of $J$. tanyorensis than that of L2 location. Therefore, appropriate soil improvement practices are required in L2 sampling location in order to improve the biochemical properties of this important species.

\section{Conflict of interest:-}

There was no conflict of interest between the two authors.

\section{Acknowledgements:-}

We wish to appreciate the contributions from Mr. Sunday Okpata, Department of Biology, and Mr Awolabi Akeem, Department of Biochemistry, Faculty of Science, Federal University Otuoke, Bayelsa State, Nigeria.

\section{References:-}

1. Greenword J.J.D. Basic techniques in population studies. In: William J. Sutherland (eds), Ecological Census Techniques. United Kingdom, Cambridge University Press, 2000, 12-105.

2. Moeller J., Gaarn H. Steckel T. and Wedebye E.B. Westermann P. Environmental sciences, biodegradation, argumentation, diesel fuels, soils contamination. Bull. Environ. Contam. Toxicol., 2008, 96 (6): $913-918$

3. Adepoju S.O. Effect of coal extraction on water, soil acidty and organic matter of Igun. Nig. Journ. Engineering, 2000, 1: 30-33

4. Etukudo, M. M., Udo, Joseph I., and Ihimikaiye, Samuel . Evaluation of eco-physiological indices of Colocasia esculenta Schott along Elebere-Emayal-Otuoke road in Bayelsa State, Nigeria. Green. Journ. Bio. Sci., 2016, 6(5):084-088.

5. Sandeep Kumar, Amita Yadav, Manila Yadav and Jaya Parkash Yadav.Effect of climate change on phytochemical diversity, total phenolic content and in vitro antioxidant activity of Aloe vera (L.) Burm.f. BMC Research Notes, 2017, 10: 60

6. Jayanthy A., Prakash K.U. and Remashree A.B. (2013). Seasonal and geographical variations in cellular characters and chemical contents in Desmodium gangeticum (L) DC. - An Ayurvedic Medicinal plant. Int. J. Herb. Med., 2013, 1:34-37

7. Nchabeleng L., Mudau F.N. and Mariga, I.K. Effects of chemical composition of wild bush tea (Athrixia phylicoides DC.) growing atlocations differing in altitude, climate and edaphic factors. J. Med. Plant Res, 2012, 6:1662-1666.

8. Odjegba V.J. and Alokaloro A.A. Simulated Drought and Salinity Modulates the Production of Phytochemicals in Acalypha wilkesiana. J. $\quad$ Plant tud., 2013, 2:105-112.

9. Abdillahi H.S., Stafford G.I., Finnie J.F and Staden J.V. Ethnobotany, phytochemistry and pharmacology of Podocarpus sensus Latissimo (S.I). S. Afr. J. Bot., 2010, 76 (1), 1-24.

10. Garboui S.S., Borg-Karlson A.K and Palsson K.Tick repellent properties of three Libyan plants. J. Med. Entomol., 2009, 46 (6): 1415- 1419. 
11. Prabakaran, A.J. and Sajatha M. Jatropha tanyorensis Ellis and Saroja, A Natural Interspecific hybride occurring in Tami Nadu India Gen. $\quad$ Res. Crop Evol., 1999. 46:213-218

12. Iwalewa, E.O., Adewumi, C.O., Omisore, N.O., Adebanji, O.A. and Azike, C.K. Proantioxidant effects and cytoprotective potentials of nine edible vegetables in Southwest. Nigeria. J. Med. Food., 2005, 8: 539-544.

13. O’Hara, M.D., Kiefer, K. Farrell, T., and Kemper, K. A review of 12 commonly usedmedicinal herbs. Arch. Family Med., 1998,7, 523-536.

14. Omobuwajo, O.R., Alade, G.O., Akanmu, M.A., Obuotor, E.M. and Osasan, S.A.Microscopic and toxicity studies on the leaves of Jatropha tanjorensis. Afr. J. Pharm. Pharmacol., 2011,5(1), 12 -17.

15. Igbinaduwa P.O, Usijoj C.O and Ugwu C.C., Phytochemical analysis and toxicological evaluation of the methanolic extract of Jatropha tanyorensis leaf. Journ. Pharm. Biores., 2011, 8:2, 86-91

16. Oboh F.O.J and Masodje, A.I. Nutritional and Antimicrobial properties of Jatropha tanyorensis leaves. American Journ. Sci. Res.2009, 4 (1): 7-10

17. Inbathamizh L. and Dr. E. Padmini. Effect of geographical properties on the phytochemical composition and antioxidant potential of Moringa oleifera flowers. BioMedRx, 2013,1(3),239-247

18. Anyang S . Statistical year book of Akwa Ibom State of Nigeria. 2013 Edn. Directorate of Statistics, Ministry of Economic Development Uyo, 2013.

19. Wokocha, R.C.and Nneke, N.. Cassava Anthracnose disease and varietal screening for resistance in Akwa ibom State of Nigeria. Journ. Agric. Sci. Tech., 2011, B 1: 889-895.

20. Niger Delta Source: Bayelsa State. (2014). http://nigeriadeltasource.com/bayelsa

21. A.O.A.C., Association of Official Analytical Chemist. Methods of analysis $\left(16^{\mathrm{h}}\right.$ Edition), Washington DC., U.S.A.1999.

22. Bohn, B.A. and Kocipai-Abyazan, R. Flavonoids and condensed tannins from the leaves of Hawaiian Vaccinium vaticulatum and $\quad$ V. $\quad$ calycinum. Pacific Science, 1994, 48:458-63.

23. Harbone, Z.B. Phytochemical methods: A guide to modern techniques of plant Analysis, Chapman and Hall, London, 1973, pp. $113-185$.

24. Obadoni, B.O. and Ochuko, P.O. Phytochemical studies and comparative efficiency of the extracts of some homoeostatic plants in Edo and Delta States of Nigeria. Glob. Journ. Pure and App. Sci., 2001, 8: 20308.

25. Pearson, D. Chemical analysis of foods. (7th Ed), Henry Edward company, Churchchill, Livingstone, London, 1976, pp. 218- 336.

26. Ano AO, Odoemelam SA and Ekwueme PO (2007). Lead and cadmium levels in soils and cassava (Manihot esculenta Crantz) along Enugu- Port Harcourt express way in Nigeria.Electronic Journal of Environmental, Agricultural and Food Chemistry. 6(5): 2024 - 031.

27. Obi, 1. U. Statistical Methods of Detecting Differences Between Treatment Means and Research Methodology Issues in Laboratory and Field Experiments. Nigeria, AP Express publishers limited, 2002.

28. Barl, B., Dragland, S. and Salamon I. The Effect of Soil Nutrients on the Phytochemical Profile of Nutraceutical Crops . Conference: Conference: Symposium on Fertilizing Crops for Functional Food, At Alberta, Canada, Volume: Chapter 6 Conference Paper - November 2002.

29. Selma M.V., Martinez-Sanchez A., Allende, A., Ros, M., Herandez, M.T., and Gil, M.I. Impact of organic soil amendments on phytochemicals and microbial quality of rocket leaves ( Eruca sativa ). J. Agric Food Chem., 2010 Jul 28;58(14):8331-7.

30. Harborne J.B. The comparative biochemistry of polyphytoalexin induction in plants. Biochem. Syst. Ecol., 1999, 27:335-367.

31. Sonal Shah, Raju Saravanan, and Narendra Atmaram Gajbhiye. Phytochemical and physiological changes in Ashwagandha (Withania somnifera Dunal) under soil moisture stress . Braz. J. Plant Physiol. vol.22 no.4 Londrina 2010

32. Etukudo, M. M., Hamilton-Amachree, A., and Roberts, E. M. I. Eco-physiological studies of elemental and proximate contents of Gnetum africanum Welw and Telfairia occidentalis Hook seeds from two Ecological Zones of Akwa Ibom State. Europ. Intern. Journ. Sci. Tech. 2015 , 4(6):47-53.

33. Osim, S. E., Odoemena, C. S., Etukudo, M.M., Okonwu, K., and Eremrena, P. Evaluation of proximate composition of fruits of Lycopersicon esculentum (Roma VF) under stress and Staking. Glob. Journ. Pure App. Sci., 2010, 16(3), 277-279.

34. Apoxi, S.O., Long, R.J., Castro, F.B and Orakor, E.R. Chemical composition and nutritive value of leaves and stems of tropical weeds. Grass and Forage Science, 2000, 55(1), 77-81.

35. Agbede, O. O. Understanding soil and plant nutrition.Nigeria: Salmon Press and Co. Ltd, 2009, pp. $20-60$. 